\title{
Penerapan Model Pembelajaran Problem Solving Untuk Meningkatkan Aktivitas Dan Hasil Belajar Ekonomi Siswa Kelas X SMA Negeri 3 Selong
}

\author{
Huzain Jailani $^{1}$ Ratna Laila Musyarrofah ${ }^{2}$ \\ ${ }^{1}$ Prodi pendidikan ekonomi, FISE Universitas Hamzanwadi \\ Email : huzainjailani.farabi@gmail.com \\ ${ }^{2}$ SMA Negeri 3 Selong, Lombok Timur
}

Received: 15 November, 2019; Accepted: 20 November, 2019; Published: 28 Desember, 2019

\begin{abstract}
Abstrak
Penelitian ini bertujuan untuk mengetahui apakah dengan diterapkannya model pembelajaran problem solving dapat meningkatkan aktivitas dan hasil belajar siswa kelas X di SMA Negeri 3 Selong tahun pembelajaran 2019 / 2020, Penelitian ini menggunakan penelitian tindakan kelas (Classroom Action Research) dengan subjek penelitian pada kelas X IPS 2 SMA Negeri 3 selong. Adapun tehnik pengumpulan data yang digunakan yakni observasi dan tes hasil belajar.

Hasil penelitian menunjukkan bahwa penerapam model pembelajaran problem solving dapat meningkatkat aktivitas dan hasil belajar siswa kelas X IPS 2 SMA Negeri 3 Selong tahun pembelajaran 2019 / 2020. Hal ini ditunjukkan dengan adanya peningkatan nilai rata-rata kelas dan ketuntasan belajar pada siklus I ke siklus II yaitu nilai rata-rata kelas sebesar 60,22 meningkat menjadi 80,87 dan ketuntasan belajar klasikal dengan nilai 43,48\% meningkat menjadi $86,96 \%$, adapun skor aktivitas belajar siswa juga menunjukkan peningkatan dengan skor 2,4 menjadi 2,8 dengan kategori cukup aktif.
\end{abstract}

Kata Kunci : Model Pembelajaran, Problem Solving. Aktivitas Belajar, Hasil Belajar

Abstract

This study studies to learn whether applying a problem solving learning model can improve learning and learning outcomes of class $\mathrm{X}$ students in SMA Negeri 3 selong 2019/2020 academic year, this study uses classroom action research (Classroom Action Research) with research subjects in class X IPS 2 SMA 3 selong. While the data collection techniques used are observation and learning achievement tests.

The results showed that the application of the problem solving learning model could increase the activities and learning outcomes of students of class X IPS 2 in SMA Negeri 3 Selong in the 2019/2020 study year. This was discussed by increasing the grade average grade and learning here during the second cycle learning ie the average grade of 60.22 increased to 80.87 and classical learning completeness with a value of $43.48 \%$ increased to $86.96 \%$, As for the score of student learning activities also showed an increase with a score of 2.4 to 2.8 with the category of quite active. 
Keywords: Learning Model, Problem Solving. Learning Activities, Learning Outcomes

\section{PENDAHULUAN}

Belajar adalah proses mental dan emosional atau proses berfikir dan merasakan (Winataputra 2004:24). Seseorang dikatakan belajar bila pikiran dan perasaannya aktif. Aktivitas pikiran dan perasaan itu sendiri tidak dapat diamati orang lain, akan tetapi terasa oleh orang yang bersangkutan (orang yang sedang belajar itu ) guru tidak dapat melihat aktifitas pikiran dan perasaan siswa yang diamati guru adalah manifestasinya, yaitu kegiatan siswa sebagai akibat adanya aktivitas pikiran dan perasaan pada diri siswa tersebut. Sebagai contoh siswa bertanya, siswa menjawab pertanyaan, siswa menanggapi, siswa melakukan diskusi, siswa memecahkan soal, siswa mengamati sesuatu, siswa melaporkan hasil pekerjaan, siswa membuat rangkuman dan sebagainya. Dalam proses belajar mengajar banyak masalah yang dihadapi oleh seorang guru, diantaranya pemilihan metode mengajar yang tepat agar tujuan pembelajaran dapat tercapai secara baik dan siswa dapat belajar secara efektif dan efesien, salah satu upaya untuk meningkatkan hasil belajar siswa yaitu memperbaiki metode pengajaran, karena belajar merupakan suatu proses komunikasi, sehingga diperlukan kemampuan khusus guru dalam mengembangkan strategi dan metode pengajaran baru untuk membantu proses belajar mengajar.

Hasil observasi dan wawancara dengan ibu ratna laila musyarafah selaku guru bidang studi ekonomi kelas X SMA Negeri 3 selong diperoleh informasi bahwa : (1) Keaktifan siswa dalam pembelajaran ekonomi kurang, dari satu kelas kurang lebih $10 \%$ saja yang aktif baik dalam bertanya maupun menjawab pertanyaan yang di ajukan oleh guru, (2) Siswa cukup sulit memahami konsepkonsep ekonomi, (3) Kurang siapnya siswa untuk mengikuti proses belajar mengajar, siswa tidak banyak yang siap atau menyiapkan diri dari sebelum pembelajaran dimulai (4) Siswa belum mampu memecahkan masalah dengan baik, yang mencerminkan keterampilan berfikir secara kritis masih kurang (5) Data hasil belajar siswa yang diperoleh relatif kurang dari ketuntasan belajar. 
Rendahnya hasil belajar disebabkan oleh penggunaan metode yang belum mengaktifkan siswa secara penuh dalam proses belajar mengajar, guru selalu menempatkan diri dalam subyek intraksi atau arah yang monolog juga mengajar masih menggunakan metode ekspositori dan didominasi dengan ceramah, sehingga tidak jarang menimbulkan suasana yang tidak kondusif dalam proses belajar mengajar. Proses belajar seperti selain membuat siswa bosan, juga dianggap kurang memberikan kesempatan pada siswa untuk mengembangkan kreativitasnya, hal ini menyebabkan aktifitas belajar tidak berjalan dengan baik sehingga hasil belajar tidak sesuai dengan indikator yang diharapkan.

Mencermati permasalahan di atas maka peneliti ingin menerapkan model pembelajaran yang diharapkan mampu mengkondisikan siswa sehingga dapat terlibat aktif dalam pembelajaran, memupuk kerja sama diantara siswa, serta melatih kemampuan berfikir siswa, secara kritis, dan mampu memecahkan pemasalah yang dihadapi, untuk itu pembelajaran yang diterapkan berupa model pembelajaran problem solving.

Model pembelajaran problem solving adalah suatu cara mengajar dengan menghadapkan siswa kepada suatu masalah agar dipecahkan atau diselesaikan Sriyono (1992). Proses pemecahan masalah memberikan kesempatan peserta didik berperan aktif dalam mempelajari, mencari, dan menemukan sendiri informasi untuk diolah menjadi konsep, prinsip, teori, atau kesimpulan. Dengan kata lain, pemecahan menuntut kemampuan memproses informasi untuk membuat keputusan tertentu (Nessinta, 2010).

Model pembelajaran problem solving ini merupakan model pembelajaran yang efektif digunakan dalam meningkatkan kemampuan siswa dalam memecahkan masalah sebagaimana hasil penelitian komaryah (2011) yakni nilai rata-rata pada siklus ke II meningkat sebesar 8,9 yaitu dari 56,1 menjadi 65. Selain itu penelitian yang dilakukan oleh sehendri, dan mardalena menunjukkan bahwa Metode problem solving terbukti secara parsial dapat meningkatkan hasil belajar matematika siswa. Selain dapat meningkatkan hasil belajar siswa model problem solving ini juga dapat meningkatkan dan mempengaruhi kemampuan berfikir kritis siswa sesuai dengan hasil penelitian 
penelitian ristiasari (2012) menunjukkan bahwa penerapan model pembelajaran problem solving dengan mind mapping berpengaruh terhadap kemampuan berpikir kritis di SMP Negeri 6 Temanggung

\section{METODE PENELITIAN}

Jenis penelitian ini adalah penelitian tindakan kelas (Classroom Action Research) dengan menerapkan model pembelajaran Problem solving. Penelitian tindakan kelas merupakan proses investigasi terkendali yang berdaur ulang dan bersifat reflektif mandiri yang dilakukan oleh guru / calon guru yang memiliki tujuan untuk melakukan perbaikan-perbaikan terhadap system,cara, kerja, proses, isi, kompetensi, atau situasi pembelajaran (Susilo : 2009). Rancangan untuk tiap siklus pada penelitian tindakan kelas sebagaimana menurut desain dari Kemmis Mc Taggart yang di awali dengan perencanaan tindakan (planning), penerapan tindakan (action), mengobservasi dan mengevaluasi proses hasil tidakan (observation and evaluation), dan refleksi (reflecting), dan seterusnya sampai perbaikan dan peningkatan yang diharapkan tercapai. Bila hasil perbaikan yang diharapkan belum tercapai pada siklus I maka diperlukan langkah lanjutan pada siklus II. Banyaknya siklus tidak dapat ditetapkan dan tergantung pada kebutuhan dan ketuntasan pemecahan masalah. Kriteria keberhasilan PTK dapat ditetapkan misalnya dengan menggunakan prinsip belajar tuntas, misalnya $75 \%$. Apabila tingkat perbaikan yang diharapkan mencapai minimal 75\% maka pencapaian itu dapat dikatakan sudah memenuhi kriteria, (Susilo dkk, 2009: 55). Tehnik analisis data yang digunakan yakni:

\section{Menghitung Nilai Rata-Rata}

Setelah diperoleh data hasil evaluasi, nilai rata-rata kelas dihitung dari skor rata-rata tes tiap siklus dengan rumus:

$$
M=\frac{\sum \mathrm{x}}{N}
$$

Keterangan:

$\mathrm{M}:$ Mean (rata-rata)

$\sum x$ : Jumlah nilai yang diperoleh oleh seluruh siswa 
$\mathrm{N}$ : Banyak siswa

Prestasi belajar siswa dikatakan meningkat apabila terdapat peningkatan rata-rata dari skor sebelumnya

(Sunartana, 1990:174)

2. Menghitung Nilai Ketuntasan Belajar Siswa Secara Klasikal

Ketuntasan belajar klasikal siswa minimal $85 \%$ siswa mendapat nilai $\geq$ 75 secara individual. Jika setiap siklus hasil yang diperoleh tidak mencapai ketuntasan belajar, yaitu minimal $85 \%$ siswa memperoleh nilai 75 maka dilanjutkan ke siklus berikutnya hingga mencapai ketuntasan belajar yaitu, $85 \%$ siswa memperoleh nilai 75 . Adapun rumus yang digunakan adalah:

$$
K B=-\times 100 \%
$$

keterangan :

KB : Ketuntasan belajar

$S:$ Banyaknya siswa yang memperoleh nilai $\geq 75$

$\mathrm{N}$ : Banyak siswa

Ketuntasan belajar dikatakan tercapai jika $K B \geq 85 \%$ (Depdikbud, 1993:2)

Adapun bagan langkah langkah PTK model Kemmis \& Mc Taggart (Susilo dkk, 2009)

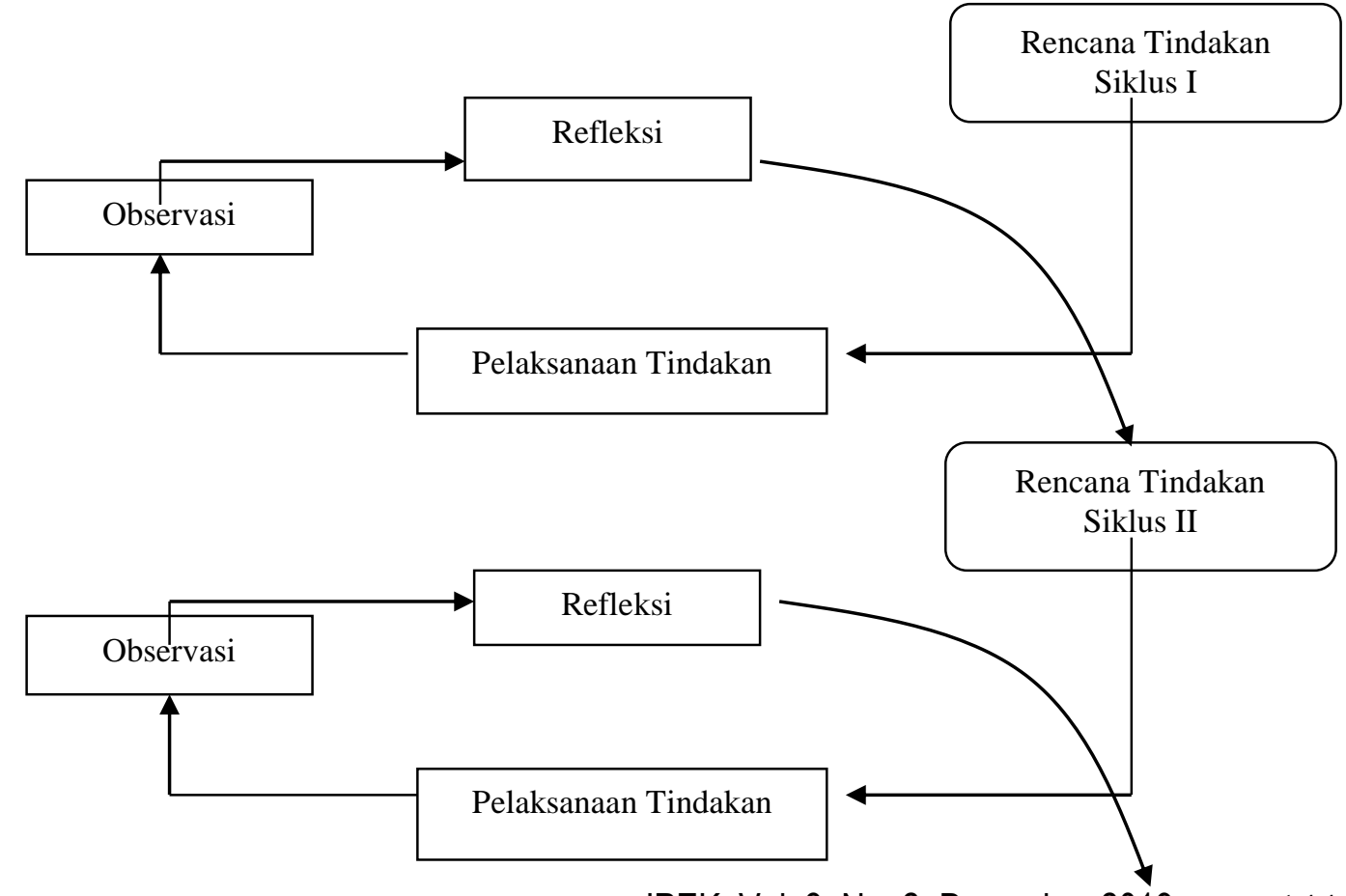




\section{Gambar : 1 Langkah-Langkah PTK Model Kemmis \& Mc Taggart}

\section{HASIL PENELITIAN}

Penelitian tindakan kelas ini dilakukan untuk meningkatkan hasil belajar ekonomi siswa pada pokok bahasan kebutuhan manusia, kelangkaan, dan sistem ekonomi tahun pelajaran 2019/2020. Penelitian ini dilakukan selama 1 bulan mulai dari tanggal 22 Juli sampai dengan 22 Agustus. untuk melihat keberhasilan penelitian ini adalah dengan melihat peningkatan nilai rata-rata dari tiap siklus dan ketuntasan belajar klasikal siswa minimal 85\% siswa mendapat nilai $\geq 75$.

Strategi untuk mencapai tujuan tersebut dengan menerapkan tindakan yang berupa model pembelajaran problem solving meliputi tahapan yakni I Can (saya mampu / bisa), I Can (saya mampu / bisa), Plan (Merencanakan), Do it (Mengerjakan), Check (mengoreksi kembali), Generalize (generalisasi). Penelitian ini di laksanakan dalam 2 siklus dengan melibatkan 23 siswa yang bertindak sebagai subjek penelitian.

Data hasil penelitian yang diperoleh diuraikan sebagai berikut:

\section{Siklus I}

\section{a. Data hasil belajar siswa}

Dari 23 siswa yang mengikuti tes evaluasi terdapat 10 siswa yang tuntas belajar, sehingga ketuntasan belajar pada siklus I adalah 43,48\%, ini menunjukkan ketuntasan belum memenuhi kriteria yang tertera dalam kurikulum bahwa kelas dikatakan tuntas secara klasikal mencapai 85\% siswa mendapat nilai $\geq 75$ dengan demikian perlu dilakukan perbaikan pada siklus II.

Data hasil belajar siswa kelas X IPS 2 SMA Negeri 3 Selong dapat dilihat pada tabel 01

Tabel : 01

Ringkasan Data Hasil Evaluasi Siklus I

\begin{tabular}{clc}
\hline No & \multicolumn{1}{c}{ Aspek penilaian } & Hasil \\
\hline 1 & Jumlah siswa yang ikut tes & 23 \\
\hline 2 & Jumlah siswa yang tuntas & 10 \\
\hline 3 & Jumlah siswa yang tidak tuntas & 13 \\
\hline 4 & Nilai tertinggi & 90 \\
\hline 5 & Nilai terendah & 35
\end{tabular}




\begin{tabular}{clc}
\hline 6 & Total nilai & 1385 \\
\hline 7 & Nilai rata-rata & 60,22 \\
\hline 8 & Prosentase ketuntasan & $43,48 \%$ \\
Sumber & Data Diolah Peneliti
\end{tabular}

Sumber : Data Diolah Peneliti

\section{b. Hasil observasi Aktivitas siswa}

Tabel : 02

Ringkasan Data Hasil Observasi Aktivitas Siswa Siklus I

\begin{tabular}{clc}
\hline \multirow{2}{*}{ No } & \multicolumn{1}{c}{ Indikator } & Skor \\
& \multicolumn{1}{c}{ Kesiapan siswa dalam mengikuti kegiatan pembelajaran } & 2,2 \\
\hline 2 & Antusiasme siswa dalam mengikuti pembelajaran & 2,3 \\
\hline 3 & Intraksi siswa dengan siswa & 2,2 \\
\hline 4 & Intraksi siswa dengan guru & 2,6 \\
\hline 5 & Kerjasama dalam kelompok & 2,5 \\
\hline 6 & Aktivitas siswa dalam diskusi kelompok & 2,4 \\
\hline 7 & Aktivitas siswa dalam pembelajaran & 2,7 \\
\hline 8 & Partisipasi siswa dalam menyimpulkan hasil belajar & 2,6 \\
\hline Jumlah skor aktivitas & 19,5 \\
\hline Rata-rata skor aktivitas & 2,4 \\
\hline Kategori & Cukup aktif \\
\hline Sumber : Data Diolah Peneliti
\end{tabular}

Kekurangan yang ditemui pada siklus I sebagai berikut:

a. Kesiapan siswa dalam mengikuti pelajaran masih kurang, hal ini terlihat dari adanya siswa yang masih berada diluar kelas pada saat guru berada didalam kelas.

b. Antusiasme siswa dalam mengikuti pelajaran masih kurang, hal ini ditunjukkan masih banyak siswa yang ribut

c. Siswa belum berani memperbaiki ataupun menanggapi kesalahan rekannya dalam menjawab soal ataupun bertanya, ini menunjukkan intraksi siswa dengan siswa dan siswa dengan guru masih kurang

d. Partisipasi siswa dalam menyimpulkan hasil belajar kurang.

Aktivitas siswa yang sudah baik yaitu: siswa mampu menyampaikan hasil diskusi (refleksi) dengan baik, siswa mampu menanyakan dan menjawab stimulus yang diberikan guru terkait dengan materi yang belum dimengerti. 


\section{Refleksi}

Dilihat dari hasil evaluasi dan observasi pada siklus I, guru perlu melakukan perbaikan-perbaikan dalam pembelajaran siklus II adapun langkah-langkah perbaikan yang dilakukan sebagai berikut;

1. Guru harus lebih memperhatikan persiapan siswa sebelum pembelajaran dimulai, seperti meminta siswa masuk kelas sebelum guru masuk, memberikan peringatan, serta meminta siswa untuk tenang dalam mengikuti pembelajaran.

2. Guru semaksimal mungkin menciptakan suasana belajar yang menyenangkan dan mampu mengendalikan kondisi yang dapat mengganggu proses belajar mengajar dengan mendatangi siswa yang ribut dan menannyakan sejauh mana pemahaman / pekerjaan dalam diskusi, mengarahkan agar ikut kerja dalam kelompok dan terkadang menunjuk untuk mempersentasikan hasil kerja

3. Lebih bisa menekankan waktu untuk setiap tahap pembelajaran

4. Berfungsi sebagai fasilitator saja dengan memberikan kesempatan pada siswa dan mengarahkan siswa untuk ikut mengambil, atau menambah, ataupun menyempurnakan kesimpulan dengan bahasa sendiri

5. Memaksimalkam model pembelajaran yang diterapkan yakni model problem soliving dengan memperhatikan sintaks aatau langkah langkah pembelajaran dengan baik

\section{Siklus II}

\section{a. Hasil Evaluasi belajar siswa}

Tabel : 03

Ringkasan Data Hasil Evaluasi Siswa Siklus II Aspek penilaian Hasil

\begin{tabular}{clc} 
No & & \\
\hline 1 & Jumlah siswa yang ikut tes & 23 \\
\hline 2 & Jumlah siswa yang tuntas & 20 \\
\hline 3 & Jumlah siswa yang tidak tuntas & 3 \\
\hline 4 & Nilai tertinggi & 100 \\
\hline 5 & Nilai terendah & 50 \\
\hline 6 & Total nilai & 1860 \\
\hline 7 & Nilai rata-rata & 80,87 \\
\hline
\end{tabular}




\begin{tabular}{ccc}
\hline $8 \quad$ Prosentase ketuntasan & $86,96 \%$ \\
\hline Sumber $:$ Data Diolah Peneliti
\end{tabular}

Dari tabel diatas dapat dilihat ketuntasan belajar dicapai oleh 23 siswa dari 23 siswa yang mengikuti tes evaluasi dengan prosentase ketuntasan belajar $86,96 \%$ Nilai ini menunjukkan telah memenuhi kriteria yang telah ditetapkan yaitu ketuntasan belajar klasikal siswa minimal 85\% siswa memperoleh nilai $\geq 75$, sehingga dapat ditarik kesimpulan bahwa ketuntasan belajar secara klasikal telah tercapai , dengan demikian penelitian dapat dihentikan.

\section{b. Hasil observasi Aktivitas siswa}

Tabel : 04

Data Ringkasan Observasi Kegiatan Siswa Siklus II

\begin{tabular}{clc}
\hline \multirow{2}{*}{ No } & \multicolumn{1}{c}{ Indikator } & Skor \\
\hline 1 & Kesiapan siswa dalam mengikuti kegiatan pembelajaran & 3 \\
\hline 2 & Antusiasme siswa dalam mengikuti pembelajaran & 2,7 \\
\hline 3 & Intraksi siswa dengan siswa & 2,7 \\
\hline 4 & Intraksi siswa dengan guru & 2,8 \\
\hline 5 & Kerjasama dalam kelompok & 2,8 \\
\hline 6 & Aktivitas siswa dalam diskusi kelompok & 2,8 \\
\hline 7 & Aktivitas siswa dalam pembelajaran & 2,9 \\
\hline 8 & Partisipasi siswa dalam menyimpulkan hasil belajar & 3 \\
\hline Jumlah skor aktivitas & 22.7 \\
\hline Rata-rata skor aktivitas & 2,8 \\
\hline Kategori & Cukup aktif \\
\hline
\end{tabular}

Sumber : Data Diolah Peneliti

Berdasarkan data hasil observasi pada tabel 4 diatas terlihat adanya peningkatan kegiatan aktivitas siswa pada siklus I dari kriteria Kurang aktif dengan jumlah rata-rata skor aktivitas 2,4 meningkat menjadi kriteria cukup aktif pada siklus II dengan jumlah rata-rata skor aktivitas 2,8. dari hasil yang diperoleh terhadap peningkatan aktivitas siswa tersebut, berarti penerapan model pembelajaran problem solving terhadap pembelajaran ekonomi pokok bahasan kebutuhan manusia, kelangkaan, dan system ekonomi dikatakan berhasil karena 
selain dapat meningkatkan hasil belajar ekonomi siswa juga dapat meningkatkan aktifitas siswa dalam pembelajaran.

\section{Refleksi}

Penelitian dengan menerapkan tindakan yang berupa model pembelajaran roblem solving dapat dikatakan berhasil, karena tujuan dari penelitian ini telah tercapai yaitu meningkatkan hasil belajar ekonomi siswa kelas X IPS 2 pada pokok bahasan kebutuhan manusia, kelangkaan, dan sistem ekonomi dari tiap siklus. Ringkasan data hasil penelitian diatas dapat dilihat pada tabel 05

Tabel : 05

Ringkasan Data Hasil Evaluasi dan Data Observasi Aktivitas Siswa Siklus I dan II

\begin{tabular}{cccc}
\hline Siklus & $\begin{array}{c}\text { Skor Rata-rata } \\
\text { Aktivitas }\end{array}$ & $\begin{array}{c}\text { Nilai Rata-rata } \\
\text { Prestasi }\end{array}$ & $\begin{array}{c}\text { Ketuntasan } \\
\text { Belajar }\end{array}$ \\
\hline I & 2,4 & 60,22 & $43,48 \%$ \\
\hline II & 2,8 & 80,87 & $86,96 \%$ \\
\hline
\end{tabular}

Sumber: data diolah peneliti

\section{KESIMPULAN}

Berdasarkan paparan hasil penelitian dapat disimpulkan bahwa penerapam model pembelajaran problem solving dapat meningkatkat aktivitas dan hasil belajar siswa kelas X IPS 2 SMA Negeri 3 Selong tahun pembelajaran 2019 / 2020. Hal ini ditunjukkan dengan adanya peningkatan nilai rata-rata kelas dan ketuntasan belajar pada siklus I yaitu 60,22 dan 43,48\% meningkat menjadi 80,87 dan 86,96\% pada siklus II, adapun skor aktivitas belajar siswa juga menunjukkan peningkatan dengan skor 2,4 menjadi 2,8 dengan kategori cukup aktif. 


\section{DAFTAR RUJUKAN}

Depdikbud. 1993. Petunjuk Pelaksanaan Penilaian di Sekolah Dasar. Jakarta: Direktorat Pendidikan Nasional

Komaryah, 2011. Penerapan Metode Pembelajaran Problem Solving Model Polya Untuk Meningkatkat Kemampuan Memecahkan Masalah Bagi Siswa Kelas Ix J Di Smpn 3 Cimahi. Prosiding Seminar Nasional Penelitian, Pendidikan Dan Penerapan MIPA, Fakultas MIPA, Universitas Negeri Yogyakarta. 181-218

Nessinta, N. 2010. Penerapan Metode Problem Solving Untuk Meningkatkan Hasil Belajar Siswa Pada Materi Pokok Asam Basa (PTK Kelas XI IPA 4 SMANegeri 10 Bandar Lampung Tahun Pelajaran 2009-2010).Skripsi. FKIP Universitas Lampung. Bandar lampung: Tidak diterbitkan

Ristiasari, Priyono, Sukaesih. 2012. Model Pembelajaran Problem Solving Dengan Mind Maping Terhadap Kemampuan Berpikir Kritis Siswa. Unnes Journal Of Biology Education. 1 (3): 35-41

Sriyono. 1992.Teknik Belajar Mengajar dalam CBSA. Rineka Cipta:Jakarta

Suhendri, Mardalena. 2013. Pengaruh Metode Pembelajaran Problem Solving Terhadap Hasil Belajar Matematika Ditinjau Dari Kemandirian Belajar. Jurnal Formatif: Jurnal Ilmiah Pendidikan MIPA. Universitas Indraprasta PGRI. 3(2):105-114

Sunartana. PPN. 1990. Evaluasi Hasil Belajar. Surabaya : Usaha Nasional

Susilo, Herawati. dkk. 2009. Penilitan Tindakan Kelas Sebagai Sarana Pengembangan Keprofesionalan Guru Dan Calon Guru. Malang : Bayumedia

Winataputra, Udin S. 2004. Strategi Belajar Mengajar. Jakarta : Universitas Terbuka 